University of New Hampshire

University of New Hampshire Scholars' Repository

Faculty Publications

$10-18-2008$

\title{
Assessment of clear and cloudy sky parameterizations for daily downwelling longwave radiation over different land surfaces in Florida, USA
}

Minha Choi

Hanyang University

Jennifer M. Jacobs

University of New Hampshire, Durham, jennifer.jacobs@unh.edu

William P. Kustas

U.S. Department of Agricultural, Beltsville

Follow this and additional works at: https://scholars.unh.edu/faculty_pubs

Comments

This is an article published by AGU in Geophysical Research Letters in 2008, available online: https://dx.doi.org/

10.1029/2008GL035731

\section{Recommended Citation}

Choi, M., J.M. Jacobs, and W. Kustas. 2008. Assessment of clear and cloudy sky parameterizations for daily downwelling longwave radiation over different land surfaces in Florida, USA. Geophysical Research Letters. 35. L20402, doi:10.1029/2008GL035731.

This Article is brought to you for free and open access by University of New Hampshire Scholars' Repository. It has been accepted for inclusion in Faculty Publications by an authorized administrator of University of New Hampshire Scholars' Repository. For more information, please contact Scholarly.Communication@unh.edu. 


\title{
Assessment of clear and cloudy sky parameterizations for daily downwelling longwave radiation over different land surfaces in Florida, USA
}

\author{
Minha Choi, ${ }^{1}$ Jennifer M. Jacobs, ${ }^{2}$ and William P. Kustas ${ }^{1}$ \\ Received 18 August 2008; revised 22 September 2008; accepted 25 September 2008; published 18 October 2008.
}

[1] Clear sky downwelling longwave radiation $\left(\mathrm{R}_{\mathrm{ldc}}\right)$ and cloudy sky downwelling longwave radiation $\left(R_{1 d}\right)$ formulas were tested across eleven sites in Florida. The Brunt equation, using air vapor pressure and temperature measurements, provides the best $\mathrm{R}_{\mathrm{ldc}}$ estimates with a root mean square error of less than around $12 \mathrm{Wm}^{-2}$ across all sites. The Crawford and Duchon's cloudiness factor with Brunt equation is recommended for $\mathrm{R}_{\mathrm{ld}}$ calculations. This combined approach requires no local calibration and estimates $R_{l d}$ with a root mean square error of less than around $13 \mathrm{Wm}^{-2}$ and squared correlation coefficients that typically exceed 0.9. Citation: Choi, M., J. M. Jacobs, and W. P. Kustas (2008), Assessment of clear and cloudy sky parameterizations for daily downwelling longwave radiation over different land surfaces in Florida, USA, Geophys. Res. Lett., 35, L20402, doi:10.1029/2008GL035731.

\section{Introduction}

[2] Net radiation is a critical component of the surface energy budget [Brutsaert, 1975; Sugita and Brutsaert, 1993; Crawford and Duchon, 1999]. Enhanced estimation of net radiation using reliable downward longwave radiation $\left(\mathrm{R}_{\mathrm{ld}}\right)$ values will contribute to a better understanding of the surface energy budget and result in improved characterization of evapotranspiration for many applications in hydrology, climatology, biology, and ecology. While $\mathrm{R}_{\mathrm{ld}}$ can be directly measured by a pyrgeometer, the instrument is rarely part of weather stations. Additionally, pyrgeometers are expensive as compared to shortwave radiation instruments and their measurements often have significant errors [Sridhar and Elliott, 2002; Duarte et al., 2006].

[3] Lacking the required data and measurements noted above, $\mathrm{R}_{\mathrm{ld}}$ can be calculated using screen height measurements of air vapor pressure and temperature from weather stations via simple physical or empirical models [Sellers, 1965; Idso and Jackson, 1969; Brutsaert, 1975; Satterlund, 1979; Sugita and Brutsaert, 1993; Prata, 1996; Crawford and Duchon, 1999; Rizou and Nnadi, 2007]. More reliable $\mathrm{R}_{\mathrm{ld}}$ estimation can be obtained by radiative transfer models such as MODTRAN [Snell et al., 1995]. However, required input data such as vertical profiles of temperature and air vapor are not typically available [Niemela et al., 2001; Duarte et al., 2006].

\footnotetext{
${ }^{1}$ Hydrology and Remote Sensing Laboratory, Agricultural Research Service, U.S. Department of Agricultural, Beltsville, Maryland, USA.

${ }^{2}$ Department of Civil Engineering, University of New Hampshire, Durham, New Hampshire, USA.
}

Copyright 2008 by the American Geophysical Union. 0094-8276/08/2008GL035731
[4] Most models make empirical estimates of atmospheric emissivity $\left(\varepsilon_{\mathrm{a}}\right)$ from measured air temperature and relative humidity. In contrast, the Brutsaert [1975] model and the Prata [1996] model which basically follows Brutsaert [1975] derivation using adjusted slab emissivity are based on analytical equations using radiative transfer theory [Kjaersgaard et al., 2007]. Both physical and empirical model parameters and performance are significantly affected by geographical location and local atmospheric conditions including cloud characteristics [Rizou and Nnadi, 2007] and require site specific validation and parameterization.

[5] The main objective of this study is to identify the best models with original parameters available to estimate $R_{l d}$ from meteorological data, resulting in reliable quantification of net radiation and evapotranspiration in Florida, United States. This study is unique compared to previous studies because: 1) it uses simultaneous measurements collected over a 2 year period at eleven experimental sites over an extensive geographical area and 2) includes both clear and cloudy sky conditions in Florida that are characteristic of humid, convective climate conditions, in the southeastern United States and other subtropical locations.

\section{Study Region and Ground Based Data}

[6] The central Florida study region has a humid, subtropical climate, with an average annual rainfall of $1500 \mathrm{~mm}$ [Black, 2003]. Almost 70\% of the annual rainfall occurs from May to November. Average annual temperature is $32.2^{\circ} \mathrm{C}$ and average annual relative humidity is higher than $50 \%$ [Black, 2003]. Average annual wind speed from Florida Automated Weather Network (FAWN, http://fawn. ifas.ufl.edu/, 2002) is about $2.2 \mathrm{~m} / \mathrm{s}$ [Black, 2003]. Thunderstorms usually occur in the afternoon during summer due to strong convective activity. During the study period, 2004 to 2005 , the average daytime cloud cover was 32\% from May to October.

[7] Data collected at eleven net radiation experiment sites (two open water, two wetland, two urban, two rangeland, one forest, and two agriculture sites) in central Florida are used in this study (Figure 1). Field locations and attributes are given in Table 1. Two years of data, January 1, 2004 to December 31, 2005, were available for this analysis. The 15 minute data were averaged to provide daily average values.

[8] Each site was instrumented with a new Kipp \& Zonen CNR1 four-channel radiometer composed of a pyranometer and pyrgeometer pair installed approximately $2 \mathrm{~m}$ above the canopy surfaces. The net radiometer measured incoming and outgoing shortwave and longwave radiation every 15 minutes. The radiometer calibration was provided by 


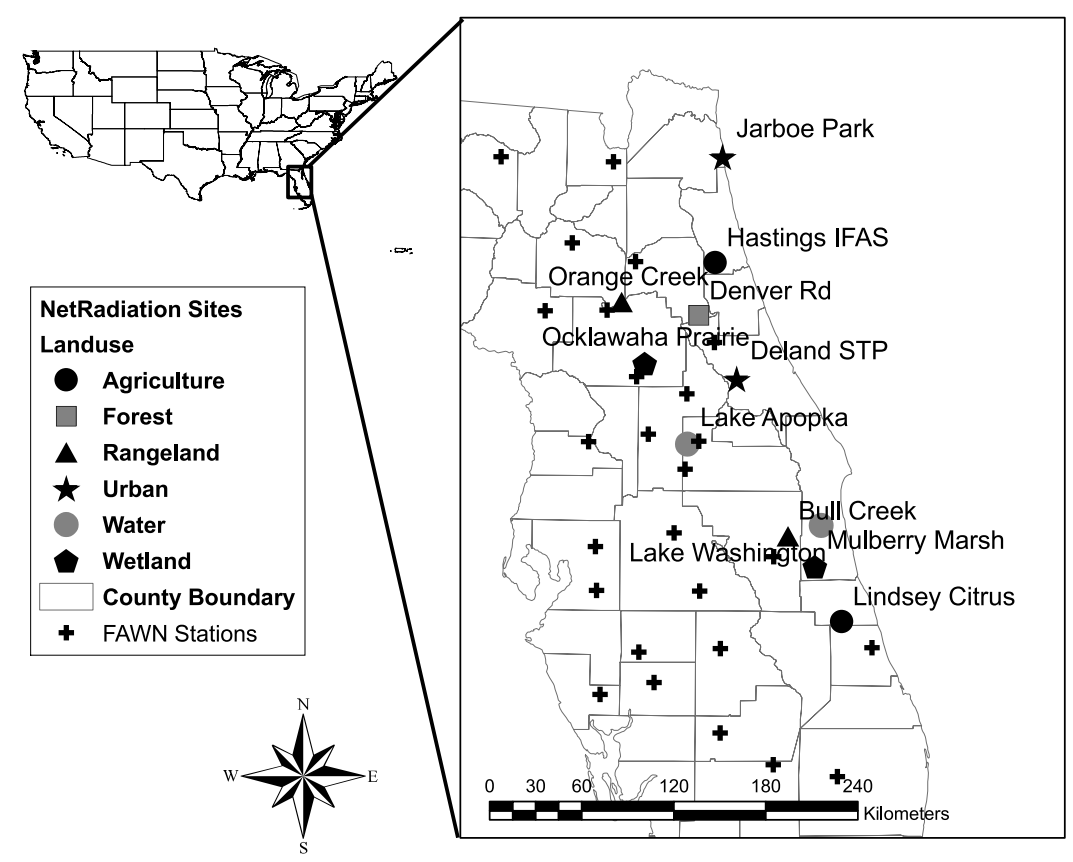

Figure 1. The eleven experimental sites in Florida at which incoming longwave radiation was measured from 2004 to 2005 and the nearby FAWN stations at which temperature and relative humidity were measured.

manufacturer. The sensitivity of the radiometer ranges from 10 to $35 \mathrm{Wm}^{-2}$ and maximum error due to heating is $10 \mathrm{Wm}^{-2}$ [Tien et al., 2008]. Systematic error of incoming longwave radiation as measured by pyrgeometer may be up to $\pm 5 \mathrm{Wm}^{-2}$ due to solar radiation and wind speed [Perez and Alados-Arboledas, 1999]. The radiometer data were quality checked weekly by comparing measurements within the same region. Radiometers were visually inspected and side-by-side comparisons were made with a dedicated reference radiometer bi-monthly. Radiometers were sent to Kipp \& Zonen for recalibration bi-annually (personal communication G. Robinson, St. Johns River Water Management District, 2008). Daily downward shortwave radiation data were plotted against theoretical clear sky downward solar radiation [Allen et al., 1998; Kjaersgaard et al., 2007] and with few exceptions were enveloped below the theoretical clear sky downward solar radiation.

[9] Daily temperature and relative humidity data were obtained from the nearby FAWN meteorological stations located within $10 \mathrm{~km}$. Each FAWN tower measures temperature and relative humidity every 15 minutes using a
Campbell Scientific CS215 probe mounted at $2 \mathrm{~m}$ (FAWN, 2002). In this study, the FAO quality assurance procedures for temperature and relative humidity were applied to the FAWN data [Allen et al., 1998].

\section{Methods}

\subsection{Clear Sky Downwelling Longwave Radiation}

[10] $R_{1 d}$ is typically estimated by first determining the clear sky radiation $\left(\mathrm{R}_{\mathrm{ldc}}\right)$, which is then corrected for cloud cover. The general form of the $\mathrm{R}_{\mathrm{ldc}}$ equation is

$$
\mathrm{R}_{\mathrm{ldc}}=\varepsilon_{\mathrm{a}} \sigma \mathrm{T}_{\mathrm{a}}^{4}
$$

where $\varepsilon_{\mathrm{a}}$ is the atmospheric emissivity, $\sigma$ is the StefanBoltzman constant $\left[\mathrm{Wm}^{-2} \mathrm{~K}^{-4}\right]$, and $\mathrm{T}_{\mathrm{a}}$ is the air temperature $[\mathrm{K}]$. The surface emissivity is typically estimated as a function of the air temperature and actual vapor pressure $\left(e_{a}\right)$. Nornally, $e_{a}$ and $T_{a}$ are measured at screen level height around $2 \mathrm{~m}$. Table 2 lists the five $R_{1 d c}$ models with original parameters that were compared.

Table 1. Florida Study Sites, Locations, Land Use, and Number of Clear and Cloudy Sky Observations From 01/01/2004 to 12/31/2005

\begin{tabular}{|c|c|c|c|c|c|}
\hline Site & Land Use & Latitude & Longitude & Count of Clear Sky Days & Count of Cloudy Sky Days \\
\hline Lake Washington & Water & 28.1 & -80.7 & 59 & 630 \\
\hline Lake Apopka & Water & 28.6 & -81.6 & 85 & 689 \\
\hline Mulberry Marsh & Wetland & 27.9 & -80.8 & 57 & 725 \\
\hline Ocklawaha Prairie & Wetland & 29.1 & -81.9 & 114 & 731 \\
\hline Jarboe Park & Urban & 30.3 & -81.4 & 107 & 731 \\
\hline Deland STP & Urban & 29.0 & -81.3 & 103 & 724 \\
\hline Bull Creek & Rangeland & 28.1 & -81.0 & 68 & 731 \\
\hline Orange Creek & Rangeland & 29.5 & -82.1 & 96 & 731 \\
\hline Denver Rd & Forest & 29.4 & -81.6 & 102 & 712 \\
\hline Hastings IFAS $^{\mathrm{a}}$ & Agriculture & 29.7 & -81.4 & 41 & 225 \\
\hline Lindsey Citrus & Agriculture & 27.6 & -80.6 & 68 & 731 \\
\hline
\end{tabular}

${ }^{\text {a}}$ Partial years. 
Table 2. $\mathrm{R}_{\mathrm{ldc}}$ Models Compared for Clear Sky Conditions ${ }^{\mathrm{a}}$

\begin{tabular}{|c|c|c|}
\hline Clear Sky Longwave Radiation & Variables & Source \\
\hline $\begin{array}{l}\mathrm{R}_{\mathrm{ldc}}=\left(\mathrm{a}_{1}+\mathrm{b}_{1} \mathrm{e}^{1 / 2}\right) \sigma \mathrm{T}_{\mathrm{a}}{ }^{4} \\
\mathrm{R}_{\text {ldc }}=\left(1-\mathrm{a}_{2} \exp \left(-\mathrm{b}_{2}\left(273-\mathrm{T}_{\mathrm{a}}\right)^{2}\right)\right) \sigma \mathrm{T}_{\mathrm{a}}{ }^{4} \\
\mathrm{R}_{\mathrm{ldc}}=\mathrm{a}_{3}\left(\mathrm{e}_{\mathrm{a}} / \mathrm{T}_{\mathrm{a}}\right)_{3}{ }^{\mathrm{b}} \sigma \mathrm{T}_{\mathrm{a}}^{4} \\
\mathrm{R}_{\mathrm{ldc}}=\left\{\mathrm{a}_{4}\left(1-\exp \left(-\mathrm{e}_{\mathrm{a}}\left(\mathrm{Ta} / \mathrm{b}_{4}\right)\right)\right)\right\} \sigma \mathrm{T}_{\mathrm{a}}{ }^{4} \\
\mathrm{R}_{\mathrm{ldc}}=\left\{1-\left(1+\mathrm{a}_{5}\left(\mathrm{e}_{\mathrm{a}} / \mathrm{T}_{\mathrm{a}}\right)\right) \exp \left(-\left(\mathrm{b}_{5}+\mathrm{a}_{5} \mathrm{c}_{5}\left(\mathrm{e}_{\mathrm{a}} / \mathrm{T}_{\mathrm{a}}\right)\right)^{1 / 2}\right)\right\} \sigma \mathrm{T}_{\mathrm{a}}^{4}\end{array}$ & $\begin{array}{c}\mathrm{a}_{1}=0.605 \mathrm{~b}_{1}=0.048 \\
\mathrm{a}_{2}=0.261 \mathrm{~b}_{2}=7.77 \times 10^{-4} \\
\mathrm{a}_{3}=1.24 \mathrm{~b}_{3}=0.14 \\
\mathrm{a}_{4}=1.08 \mathrm{~b}_{4}=2016 \\
\mathrm{a}_{5}=46.5 \mathrm{~b}_{5}=1.20 \mathrm{c}_{5}=3.0\end{array}$ & $\begin{array}{l}\text { Brunt }[1932]^{\mathrm{b}} \\
\text { Idso and Jackson }[1969] \\
\text { Brutsaert }[1975] \\
\text { Satterlund }[1979] \\
\text { Prata }[1996]\end{array}$ \\
\hline
\end{tabular}

\subsection{Cloudy Sky Downwelling Longwave Radiation}

[11] Under cloudy conditions, fractional cloud cover required to estimate $R_{l d}$ may be determined from visual observations. However, when fractional cloud cover measurements are not available, they can be estimated by Crawford and Duchon [1999] equation

$$
\mathrm{c}=1-\mathrm{R}_{\mathrm{s}} / \mathrm{R}_{\mathrm{so}}
$$

where $R_{s}$ is the downward solar radiation at the surface and $\mathrm{R}_{\text {so }}$ is the theoretical clear sky downward solar radiation [Allen et al., 1998]. However, this equation can be used for only daylight hours [Duarte et al., 2006]. We identified clear sky days at the 11 sites as those days having average $\mathrm{c}$ values less than 0.05 [Duarte et al., 2006]. The clear sky calculations were conducted for only these days, while cloudy sky calculations were conducted using all days (Table 1).

[12] Cloudy sky downwelling longwave radiation formulations generally have one of two basic structures [Duarte et al., 2006].

$$
\begin{gathered}
\mathrm{R}_{\mathrm{ld}}=\mathrm{R}_{\mathrm{ldc}}\left(1+\alpha \mathrm{c}^{\beta}\right) \\
\mathrm{R}_{\mathrm{ld}}=\mathrm{R}_{\mathrm{ldc}}\left(1-\mathrm{c}^{\gamma}\right)+\delta \mathrm{c}^{\zeta} \sigma \mathrm{T}_{\mathrm{a}}^{4}
\end{gathered}
$$

where $\alpha, \beta, \gamma, \delta$, and $\zeta$ are the locally calibrated constants determined from cloud types. Seven cloudy sky correction models with original parameters were evaluated in this study (Table 3).

\section{Results and Discussion}

\subsection{Estimation for Clear Sky Downwelling Longwave Radiation}

[13] The $\mathrm{R}_{1 \mathrm{dc}}$ models were applied for those days having clear sky conditions as indicated by fractional cloud cover values less than 0.05 . For this region, only 5 to $20 \%$ of all available days are clear sky days (Table 1 ). The majority of these days were during the winter and spring. Three statistics, the root mean square error $(R M S E=$ $\left.\left[\left(\sum_{i=1}^{n}\left(\text { observed }_{i}-\text { calculated }_{i}\right)^{2} / n\right)\right]^{1 / 2}\right)$, the ratio of the calculated mean to the observed mean (RCO), and the squared correlation coefficient $\left(\mathrm{R}^{2}\right)$, were used to compare calculated $R_{\text {ldc }}$ values to observed $R_{\text {ldc }}$ values (Table 4).

[14] All the methods overestimated the measured $R_{1 d c}$. The Satterlund [1979] equation had the largest systematic and random errors and the highest bias as compared to the other equations. The two methods, the Brutsaert [1975] model and the Brunt [1932] model using the coefficients obtained by Sellers [1965], performed the best. While the Brutsaert [1975] equation had the best agreement with observed data (average $\mathrm{R}^{2}=0.871$ ), the Brunt [1932] equation had the lowest RMSE (average RMSE $=$ $12.3 \mathrm{Wm}^{-2}$ ) and $\mathrm{RCO}$ values closest to one (average $\mathrm{RCO}=$ 1.014) values (Table 4). Of the 11 experiment sites, the Ocklawaha Prairie and Deland STP sites had more scatter as compared to the other sites. This may be due to multiple land covers surrounding the sites [Rizou and Nnadi, 2007].

[15] The average RMSE values predicted by the Brunt [1932] and the Brutsaert [1975] equations were low compared to all other selected clear sky equations regardless of land cover types. Sridhar and Elliott [2002], Duarte et al. [2006], Kjaersgaard et al. [2007], and Rizou and Nnadi [2007] agreed that the Brutsaert [1975] equation was the best method to predict $\mathrm{R}_{\mathrm{ldc}}$. Sugita and Brutsaert [1993] and Kjaersgaard et al. [2007] pointed out that the Brunt [1932] equation provided a similar results to the Brutsaert [1975] equation. For this region, both the Brunt [1932] and the Brutsaert [1975] equations with existing parameterizations are viable methods to estimate $\mathrm{R}_{\mathrm{ldc}}$ with the Brunt [1932] equation performing slightly better.

[16] The value of regionally calibrated parameters was examined for $\mathrm{a}_{1}$ and $\mathrm{b}_{1}$ of the Brunt [1932] equation and $a_{3}$ and $b_{3}$ of the Brutsaert [1975] equation. Using the 11 sites, the regional calibration of Brunt [1932] equation parameters is $\mathrm{a}_{1}=0.575$ and $\mathrm{a}_{2}=0.054$ and for the Brutsaert [1975] equation, the values are $\mathrm{a}_{3}=1.14$ and $\mathrm{b}_{3}=$ 0.13 . These values are quite similar to Brunt's [1932] original values obtained by Sellers [1965] (0.605 and 0.048 ) and Brutsaert's [1975] original values (1.24 and $0.14)$. Interestingly when the $e_{a}$ units are converted from $\mathrm{hPa}$ to $\mathrm{Pa}$, the Brutsaert [1975] $\mathrm{a}_{3}$ value becomes $1.14 \times(1 / 100)^{0.13}=0.626$; this pair of values, 0.626 and 0.13 is virtually identical to that obtained by Duarte et al. [2006] (whose $e_{a}$ is in $\mathrm{Pa}$ ) at their Ponta Grossa, Brazil site: $a_{3}=0.625$ and $b_{3}=0.131$.

Table 3. $\mathrm{R}_{l d}$ Models Compared for All Measurement Periods ${ }^{\mathrm{a}}$

\begin{tabular}{ll}
\hline \multicolumn{1}{c}{ Cloudy Sky Longwave Radiation } & \multicolumn{1}{c}{ Source } \\
\hline $\mathrm{R}_{\mathrm{ld}}=\mathrm{R}_{\mathrm{ldc}}(1+0.26 \mathrm{c})$ & Jacobs $[1978]$ \\
$\mathrm{R}_{\mathrm{ld}}=\mathrm{R}_{\mathrm{ldc}}\left(1+0.22 \mathrm{c}^{2.75}\right)$ & Maykut and Church [1973] \\
$\mathrm{R}_{\mathrm{ld}}=\mathrm{R}_{\mathrm{ldc}}\left(1+0.0496 \mathrm{c}^{2.45}\right)$ & Sugita and Brutsaert $[1993]$ \\
$\mathrm{R}_{\mathrm{ld}}=\mathrm{R}_{\mathrm{ldc}}\left(1-\mathrm{c}^{4}\right)+0.952 \mathrm{c}^{4} \sigma \mathrm{T}_{\mathrm{a}}{ }^{4}$ & Konzelmann et al. $[1994]$ \\
$\mathrm{R}_{\mathrm{ld}}=\mathrm{R}_{\mathrm{ldc}}(1-\mathrm{c})+\mathrm{c} \sigma \mathrm{T}_{\mathrm{a}}^{4}$ & Crawford and Duchon [1999] \\
$\mathrm{R}_{\mathrm{ld}}=\mathrm{R}_{\mathrm{ldc}}\left(1+0.242 \mathrm{c}^{0.583}\right)$ & Duarte et al. [2006, \\
$\mathrm{R}_{\mathrm{ld}}=\mathrm{R}_{\mathrm{ldc}}\left(1-\mathrm{c}^{0.671}\right)+0.990 \mathrm{c}^{0.671} \sigma \mathrm{T}_{\mathrm{a}}{ }^{4}$ & equation $(21)]$ \\
& Duarte et al. $[2006$, \\
\hline
\end{tabular}

${ }^{\mathrm{a}} \mathrm{Here} \mathrm{c}$ is the fractional cloud cover, $\mathrm{e}_{\mathrm{a}}$ is vapor pressure $\left[10^{-3} \mathrm{bar}\right]$, and $\mathrm{T}_{\mathrm{a}}$ is air temperature $[\mathrm{K}]$. 
Table 4. Comparison of Daily Clear Sky Downwelling Longwave Radiation Results for Each $\mathrm{R}_{\mathrm{ldc}}$ Model by Site and Averaged Across Sites for Days When Fractional Cloud Cover is Less Than $5 \%^{\mathrm{a}}$

\begin{tabular}{|c|c|c|c|c|c|c|c|c|c|c|c|c|}
\hline \multirow[b]{2}{*}{ Site } & \multirow[b]{2}{*}{$\begin{array}{l}\text { Land } \\
\text { Use }\end{array}$} & \multirow[b]{2}{*}{$\begin{array}{c}\text { Measured } \\
\left(\mathrm{Wm}^{-2}\right)\end{array}$} & \multicolumn{5}{|c|}{ Calculated $\mathrm{R}_{\mathrm{ldc}}\left(\mathrm{Wm}^{-2}\right)$} & \multicolumn{5}{|c|}{$\begin{array}{l}\text { Ratio of the Calculated Mean to } \\
\text { Observed Mean (RCO) }(-)\end{array}$} \\
\hline & & & $\begin{array}{l}\text { Brunt } \\
{[1932]}\end{array}$ & $\begin{array}{c}\text { Brutsaert } \\
\text { [1975] }\end{array}$ & $\begin{array}{c}\text { Idso and } \\
\text { Jackson [1969] }\end{array}$ & $\begin{array}{c}\text { Satterlund } \\
{[1979]}\end{array}$ & $\begin{array}{l}\text { Prata } \\
{[1996]}\end{array}$ & $\begin{array}{c}\text { Brunt } \\
{[1932]}\end{array}$ & $\begin{array}{c}\text { Brutsaert } \\
{[1975]}\end{array}$ & $\begin{array}{c}\text { Idso and } \\
\text { Jackson [1969] }\end{array}$ & $\begin{array}{c}\text { Satterlund } \\
\text { [1979] }\end{array}$ & $\begin{array}{l}\text { Prata } \\
\text { [1996] }\end{array}$ \\
\hline Lake Washington & Water & 307 & 306 & 311 & 312 & 325 & 314 & 0.996 & 1.013 & 1.017 & 1.058 & 1.022 \\
\hline Lake Apopka & Water & 301 & 299 & 303 & 306 & 318 & 306 & 0.993 & 1.008 & 1.018 & 1.059 & 1.019 \\
\hline Mulberry Marsh & Wetland & 289 & 298 & 302 & 305 & 318 & 306 & 1.031 & 1.046 & 1.057 & 1.099 & 1.058 \\
\hline Ocklawaha Prairie & Wetland & 296 & 301 & 305 & 308 & 320 & 308 & 1.016 & 1.032 & 1.042 & 1.082 & 1.043 \\
\hline Jarboe Park & Urban & 292 & 295 & 300 & 300 & 314 & 303 & 1.012 & 1.028 & 1.028 & 1.077 & 1.039 \\
\hline Deland STP & Urban & 297 & 291 & 295 & 298 & 311 & 299 & 0.981 & 0.994 & 1.004 & 1.047 & 1.006 \\
\hline Bull Creek & Rangeland & 282 & 291 & 295 & 299 & 312 & 299 & 1.034 & 1.047 & 1.061 & 1.106 & 1.061 \\
\hline OrangeCreek & Rangeland & 277 & 288 & 291 & 296 & 308 & 295 & 1.037 & 1.047 & 1.067 & 1.110 & 1.064 \\
\hline Denver Rd & Forest & 296 & 296 & 300 & 303 & 315 & 304 & 0.999 & 1.013 & 1.022 & 1.065 & 1.025 \\
\hline Hastings IFAS1 & Agriculture & 303 & 311 & 317 & 315 & 329 & 319 & 1.025 & 1.047 & 1.040 & 1.086 & 1.052 \\
\hline Lindsey Citrus & Agriculture & 291 & 300 & 305 & 307 & 320 & 308 & 1.032 & 1.049 & 1.055 & 1.100 & 1.059 \\
\hline \multirow[t]{3}{*}{ Average } & & 294 & 298 & 302 & 304 & 317 & 305 & 1.014 & 1.029 & 1.037 & 1.081 & 1.041 \\
\hline & & & \multicolumn{5}{|c|}{$\operatorname{RMSE}\left(\mathrm{Wm}^{-2}\right)$} & \multicolumn{5}{|c|}{$\mathrm{R}^{2}(-)$} \\
\hline & $\begin{array}{l}\text { Land } \\
\text { Use }\end{array}$ & $\begin{array}{c}\text { Measured } \\
\left(\mathrm{Wm}^{-2}\right)\end{array}$ & $\begin{array}{l}\text { Brunt } \\
{[1932]}\end{array}$ & $\begin{array}{c}\text { Brutsaert } \\
{[1975]}\end{array}$ & $\begin{array}{c}\text { Idso and } \\
\text { Jackson [1969] }\end{array}$ & $\begin{array}{c}\text { Satterlund } \\
\text { [1979] }\end{array}$ & $\begin{array}{l}\text { Prata } \\
{[1996]}\end{array}$ & $\begin{array}{c}\text { Brunt } \\
{[1932]}\end{array}$ & $\begin{array}{c}\text { Brutsaert } \\
{[1975]}\end{array}$ & $\begin{array}{c}\text { Idso and } \\
\text { Jackson [1969] }\end{array}$ & $\begin{array}{c}\text { Satterlund } \\
\text { [1979] }\end{array}$ & $\begin{array}{l}\text { Prata } \\
{[1996]}\end{array}$ \\
\hline Lake Washington & Water & 307 & 8.9 & 08 & 11.5 & 20.4 & 11.1 & 0.926 & 0.928 & 0.905 & 0.919 & 0.926 \\
\hline Lake Apopka & Water & 301 & 10.8 & 11.9 & 12.7 & 20.7 & 12.1 & 0.875 & 0.875 & 0.850 & 0.865 & 0.876 \\
\hline Mulberry Marsh & Wetland & 289 & 12.7 & 16.2 & 19.4 & 30.3 & 19.0 & 0.910 & 0.911 & 0.894 & 0.904 & 0.911 \\
\hline Ocklawaha Prairie & Wetland & 296 & 16.1 & 18.3 & 20.5 & 28.9 & 19.9 & 0.801 & 0.806 & 0.776 & 0.795 & 0.802 \\
\hline Jarboe Park & Urban & 292 & 10.7 & 13.0 & 13.9 & 24.8 & 15.1 & 0.900 & 0.904 & 0.880 & 0.898 & 0.900 \\
\hline Deland STP & Urban & 297 & 12.5 & 11.7 & 12.1 & 18.0 & 11.2 & 0.854 & 0.857 & 0.825 & 0.847 & 0.855 \\
\hline Bull Creek & Rangeland & 282 & 13.5 & 16.7 & 20.1 & 31.4 & 19.7 & 0.793 & 0.800 & 0.758 & 0.788 & 0.794 \\
\hline OrangeCreek & Rangeland & 277 & 14.5 & 16.5 & 22.0 & 32.4 & 20.5 & 0.867 & 0.877 & 0.820 & 0.857 & 0.868 \\
\hline Denver Rd & Forest & 296 & 9.1 & 9.7 & 12.6 & 21.5 & 11.6 & 0.927 & 0.932 & 0.898 & 0.920 & 0.929 \\
\hline Hastings IFAS1 & Agriculture & 303 & 14.0 & 18.2 & 16.9 & 28.7 & 19.6 & 0.810 & 0.811 & 0.831 & 0.834 & 0.813 \\
\hline Lindsey Citrus & Agriculture & 291 & 12.5 & 16.5 & 18.5 & 30.3 & 19.0 & 0.878 & 0.880 & 0.845 & 0.869 & 0.879 \\
\hline Average & & 294 & 12.3 & 14.4 & 16.4 & 26.1 & 16.3 & 0.867 & 0.871 & 0.844 & 0.863 & 0.868 \\
\hline
\end{tabular}

${ }^{\mathrm{a}}$ Bold indicates key point numbers discussed in the text.

[17] While these locally calibrated equations provide marginally better results as compared to original equations, the original parameterizations are recommended because they provide a consistent approach across a broader region and range of field conditions [Sugita and Brutsaert, 1993].

\subsection{Estimation for Cloudy Sky Downwelling Longwave Radiation}

[18] The seven methods that account for cloud cover (Table 3) were compared for all sites and days from 01/ 01/2004 to 12/31/2005 (Table 1). The Brunt [1932] clear sky radiation equations using the original parameters was used to estimate $\mathrm{R}_{\mathrm{ldc}}$ for all seven methods. The results are summarized in Table 5. The Jacobs [1978] equation, the Crawford and Duchon [1999] equation, and the Duarte et al. [2006, equation (22)] provide excellent results with average RMSE values within $5 \%$ of the average measured values and very strong correlations with modest positive biases (Table 5). With respect to bias, our results are similar to Duarte et al.'s [2006] finding that the Maykut and Church [1973], the Sugita and Brutsaert [1993], and the Konzelmann et al. [1994] equations all underestimated the cloudy sky radiation. This is likely caused by differences between the ratio of the daytime cloud cover and nocturnal cloud cover between sites as well as the relative simple method used to estimate cloud cover.

[19] Overall, the Crawford and Duchon [1999] equation with the lowest RMSE values (average RMSE $=13.4 \mathrm{Wm}^{-2}$ ) is recommended for $\mathrm{R}_{\mathrm{ld}}$ calculation in Florida. Even the worst performing method, the Sugita and Brutsaert [1993] method developed for the relatively dry mid-western region of the United States, gave reasonable results for this region.

[20] The results were fairly consistent across land uses. The open water sites had modestly higher downwelling longwave radiation as compared to the other land uses. All of the radiation models were able to capture these observed increases.

\section{Conclusion}

[21] In this study, daily $R_{1 d}$ estimation methods were compared under clear and cloudy sky at eleven sites in Florida. The Brunt [1932] and the Brutsaert [1975] equations are both viable methods to estimate clear sky radiation with the Brunt [1932] equation performing slightly better across all sites. Regionalized parameters were quite similar to the original parameters and did not appreciably improve estimates. The recommended approach to estimate downwelling longwave radiation in Florida is to use the Brunt [1932] equation for $\mathrm{R}_{\mathrm{ldc}}$ and the Crawford and Duchon [1999] equation for $\mathrm{R}_{\mathrm{ld}}$. While more specific parameterization may be employed using cloud properties and profile temperature and humidity data, these recommended $R_{\mathrm{ldc}}$ and $R_{l d}$ methods will provide reasonable estimates with relatively high accuracy and low errors under typical convective cloud conditions in Florida. 


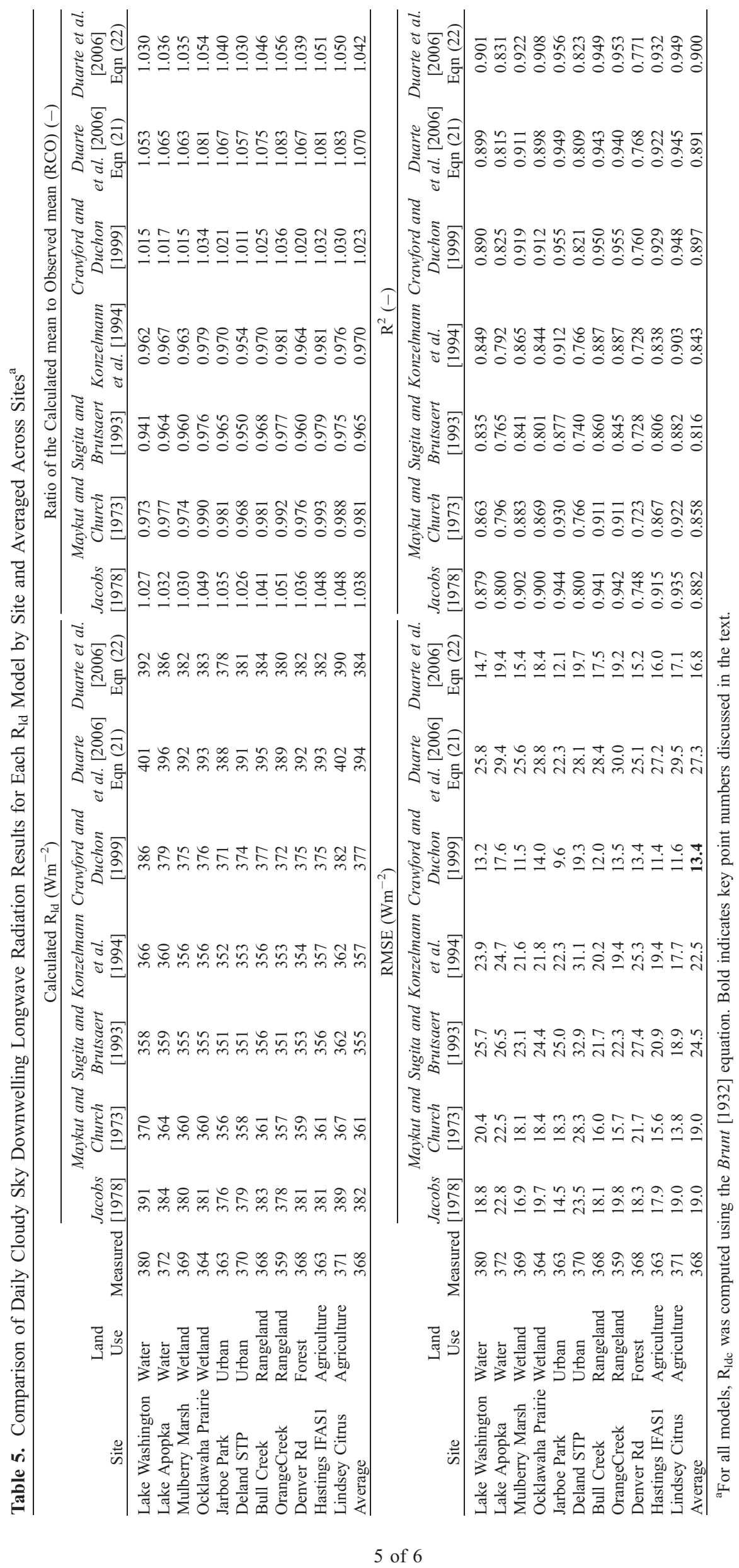


[22] Acknowledgments. This research was supported by cooperative funding from the Florida Water Management Districts administered by the US Geological Survey. The authors thank David Sumner at Florida Integrated Science Center, USGS, Chandra Pathak at the South Florida Water Management District and George Robinson at the St. Johns River Water Management District.

\section{References}

Allen, R. G., L. Pereira, D. Raes, and M. Smith (1998), Crop evapotranspirationm, FAO Irrig. Drain. Pap. 56, Water Resour. Dev. and Manage. Serv., Food and Agric. Org. of the U. N., Rome.

Black, R. J. (2003), Florida Climate Data, Inst. of Food and Agric. Sci., Univ. of Fla., Gainesville.

Brunt, D. (1932), Notes on radiation in the atmosphere, Q. J. R. Meteorol. Soc., 58, 389-420.

Brutsaert, W. H. (1975), On a derivable formula for long-wave radiation from clear skies, Water Resour. Res., 11, 742-744.

Crawford, T. M., and C. E. Duchon (1999), An improved parameterization for estimating effective atmospheric emissivity for use in calculating daytime downwelling longwave radiation, J. Appl. Meteorol., 38, 474-480.

Duarte, H. F., N. L. Dias, and S. R. Maggiotto (2006), Assessing daytime downward longwave radiation estimates for clear and cloudy skies in southern Brazil, Agric. For. Meteorol., 139, 171-181.

Idso, S. B., and R. D. Jackson (1969), Thermal radiation from the atmosphere, J. Geophys. Res., 74, 5397-5403.

Jacobs, J. D. (1978), Radiation climate of Broughton Island, in Energy Budget Studies in Relation to Fast-Ice Breakup Processes in Davis Strait, edited by R. G. Barry and J. D. Jacobs, Inst. Arct. Alp. Res. Occas. Pap. 26, pp. 105-120, Univ. of Colo., Boulder.

Kjaersgaard, J. H., F. L. Plauborg, and S. Hansen (2007), Comparison of models for calculating daytime long-wave irradiance using long term data set, Agric. For. Metoorol., 143, 49-63.

Konzelmann, T., R. S. W. van d Wal, W. Greuell, R. Bintanja, E. A. C. Henneken, and A. Abe-Ouchi (1994), Parameterization of global and longwave incoming radiation for the Greenland ice sheet, Global Planet. Change, 9, 143-164.

Maykut, G. A., and P. E. Church (1973), Radiation climate of Barrow, Alaska, 1962-1966, J. Appl. Meteorol., 12, 620-628.
Niemela, S., P. Raisanen, and H. Savijarvi (2001), Comparison of surface radiative flux parameterizations, part I: Long-wave radiation, Atmos. Res., 58, 1-18.

Perez, M., and L. Alados-Arboledas (1999), Effects of natural ventilation and solar radiation on the performance of pyrgeometers, J. Atmos. Oceanic Technol., 16, 174-180.

Prata, A. J. (1996), A new long-wave formula for estimating downward clear-sky radiation at the surface, $Q . J$. R. Meteorol. Soc., 122, $1127-$ 1151.

Rizou, M., and F. Nnadi (2007), Land use feedback on clear sky downward longwave radiation: A land use adapted model, Int. J. Clim., 27, 14791496, doi:10.1002/joc.1476.

Satterlund, D. R. (1979), An improved equation for estimating long-wave radiation from the atmosphere, Water Resour. Res., 15, 1649-1650.

Sellers, W. D. (1965), Physical Climatology, Univ. of Chicago Press, 272 pp., Chicago, Ill.

Snell, H. E., G. P. Anderson, J. Wang, J. L. Moncet, J. H. Chetwynd, and S. J. English (1995), Validation of FASE (FASCODE for the Environment) and MODTRAN3: updates and comparisons with clear-sky measurements, Proc. SPIE Int. Soc. Opt. Eng., 2578, 194-204.

Sridhar, V., and R. L. Elliott (2002), On the development of a simple downwelling longwave radiation scheme, Agric. For. Meteorol., 112, $237-243$.

Sugita, M., and W. Brutsaert (1993), Cloud effect in the estimation of instantaneous downward longwave radiation, Water Resour. Res., 29, $599-605$.

Tien, K. C., J. Judge, L. W. Miller, and O. L. Lanni (2008), Field data report for the first Micorwave Water and Energy Balance Experiment (MicroWEX-1), July 17-December 16, 2003, Citra, Florida, Inst. of Food and Agric. Sci., Univ. of Fla., Gainesville.

M. Choi and W. P. Kustas, Hydrology and Remote Sensing Laboratory, Agricultural Research Service, U.S. Department of Agricultural, Beltsville, MD 20705, USA. (minha.choi@ars.usda.gov)

J. M. Jacobs, Department of Civil Engineering, University of New Hampshire, Durham, NH 03824, USA. 